\title{
AN ANALYTICAL STUDY ON SECURITIZATION-THE FINANCIAL INSTRUMENT OF THE NEW ERA AND ITS PERFORMANCE MANAGEMENT IN INDIA
}

\author{
DR. DEEPA CHAVAN ${ }^{1} \&$ DR. MAKARAND UPADHYAYA ${ }^{2}$ \\ ${ }^{1}$ Sydenham Institute of Management Studies, Research and Entrepreneurship Education, Mumbai, India \\ ${ }^{2}$ Associate Professor-Marketing, Department of Management \& Marketing, College of Business Administration, University of \\ Bahrain, Sikhar, Kingdom of Bahrain
}

\begin{abstract}
Securitization as a money related instrument has had an amazingly noteworthy effect on the world's monitory framework. The paper examines the reaction of Indian banking system to securitization. To begin with, by incorporating capital markets and the employments of assets -, for example, contract originaftors, money organizations, governments, and so forth - it has reinforced the pattern towards disintermediation. Having had the option to moderate organization costs, it has made loaning increasingly proficient; proof of this can be seen in the home loan markets. By allowing firms to begin and hold resources off the asset report, it has created a lot of more significant levels of influence and, however apparently, more prominent economies of scale.

In its broadest sense, the expression "securitization" infers a procedure by which a budgetary relationship is changed over into an exchange. A monetary exchange is the meeting up of at least two elements; a money related relationship is their remaining together. We discover a few models throughout the entire existence of the advancement of fund of connections that have been changed over into exchanges.

This research paper has used SPSS -20, word and excels. The researcher will be taking in to consideration many research journals, websites, books and articles. The methodology will also use descriptive analysis, Paired Samples Correlations and others.
\end{abstract}

KEYWORDS: Integrating Capital Markets, Leverage, Financial Transformation, Special Purpose Vehicle

Received: Jun 05, 2020; Accepted: Jun 25, 2020; Published: Jul 30, 2020; Paper Id.: IJMPERDJUN2020533

\section{INTRODUCTION}

One of the most visible improvements in universal money in ongoing decades and the one that is probably going to expect much more noteworthy significance in future is securitization. The most widely recognized methods for financing this development has been to change over bank credits into attractive protections by the benefit securitization. In a securitization, an organization sells illiquid advantages for another lawful element, called particular reason vehicle (SPV), and the SPV accounts the buy through the issuance of new protections. To the degree that securitization influences the arrival, liquidity and danger of the merchant, we would anticipate constructive outcomes on investor riches. In this line, a couple of observational investigations have examined the adjustments in riches for banks that securitize resources happening on the US showcase.

Securitization is the way toward pooling and repackaging of homogenous illiquid money related resources into attractive protections that can be offered to speculators. The procedure prompts the formation of monetary instruments that speak to proprietorship enthusiasm for, or are made sure about by an isolated pay delivering resource or pool of advantages. The pool of advantages collateralizes protections. These benefits are for the most 
part made sure about by close to home or genuine property (for example autos, land, or hardware credits), however sometimes are unbound (for example Visa obligation, purchaser credits). The touchstones of securitization are:

- Legal genuine offer of advantages for a SPV with barely characterized purposes and exercises

- Issuance of protections by the SPV to the financial specialists collateralized by the basic resources

- Reliance by the financial specialists on the presentation of the benefits for reimbursement - instead of the credit of their Originator (the dealer) or the guarantor (the SPV)

Securitization is the way toward pooling different sorts of obligation - contracts, vehicle advances, or charge card obligation, for instance - and bundling that obligation as bonds, go through protections, or collateralized contract commitments (CMOs), which are offered to speculators.

The head and enthusiasm on the obligation hidden the security is paid to the speculators all the time, however the strategy fluctuates dependent on the kind of security. Obligations sponsored by contracts are known as home loan upheld protections, while those supported by different kinds of credits are known as resource supported protections. A credit to a company is a money related relationship; when the advance is changed into a tradable security, it is an exchange.

Securitization, in its most essential structure, is a technique for selling resources. As opposed to selling those advantages "entire", the benefits are consolidated into a pool, and afterward that pool is part into shares. Those offers are offered to speculators who share the hazard and award of the presentation of those advantages. It tends to be seen as being like a partnership selling, or "turning off," a productive specialty unit into a different substance. They exchange their responsibility for unit, and all the benefit and misfortune that may come later on, for money at the present time. The conventional requirement for securitization is as old as that for sorted out money related markets. From the differentiation between a budgetary connection and a money related exchange before, we comprehend that a connection perpetually needs the meeting up and staying together of two substances. Not that the two substances would fundamentally meet up of their own, or legitimately. They may include various budgetary mediators all the while, yet in any case, a connection includes fixity over a specific time. For the most part, money related relations are made to back another budgetary connection, for example, a credit being taken to gain an advantage, and all things considered, the required fixed time of the connection depends on the other which it looks to back-up. Money related markets created because of the need to include countless financial specialists in the commercial center. As the quantity of financial specialists continues expanding, the normal size per speculators continues descending - this is a straightforward principle of the commercial center, since developing size methods contribution of a more extensive base of speculators. The little speculator is anything but an expert financial specialist: he isn't as such in the matter of ventures. Henceforth, he needs an instrument which is clearer, and is fluid. These two needs set up for development of monetary instruments which would change over budgetary cases into fluid, straightforward and homogenous items, on occasion conveying ensured quality marks (FICO assessments or security), which would be accessible in little sections to suit each one's handbag. In this way, securitization from a nonexclusive perspective is fundamental to the universe of account, and it is an adage to state that securitization envelopes the whole scope of money related instruments, and consequently, the whole scope of monetary markets. 


\section{LITERATURE REVIEW}

Securitization is the market development that picked up ubiquity and acknowledgment in the mid 980s and step by step got more grounded in 1990s in the states, as indicated by the Bank for International Settlement (2005). According to (Davidson, Saunders, Wolff and Ching,2011) the way toward bundling money related procedure and changing them into a structure whereby they can be unreservedly moved among the large number of speculators is securitization. Fifth credit enhancer or money related underwriter is another basic component in the exchanges, while credit rating assessments of the issues is most vulnerable point and its relies upon the nature of the credit enhancer, the enhancer evaluated separately incorporates originators in the event that he is the acknowledge enhancer for that like in India originators himself is the administration should be acceptable help (Kothari, 2006). The solution of moral -Hazard problem proposed; that while offering loan to buyers an incentive - efficient sales of loan contract provide a partial solution of moral hazard problem it leads to the increases the volume of loan sales and maximize its profitability (Pennacchi,1988). (Pennacchi, 1988). While an exact examinations shows that, Finance related organization or banks only includes in the advance deals exchanges and repudiate on non - plan of action advance potential customers to originators or FI to only holder of the non-attractive cases in the organizations, associated with the verifiable assurances. tragically, they don't come on the resolution on the equalization treatment of the bank credit deals (Gortan and Pennacchi, 1989). Valid, most pragmatists utilizing components are sociologists who base the investigation on a not only utilitarian comprehension of judiciousness. There, the pretended by Werterationalität is equivalent to, if not a higher priority than, the job of instrumental discernment (Boudon, 1998). In asset supported protections, Originators has three motivating forces to expels this ethical risk issue. These three are originators can spare the first - misfortune hazard ensure, can create the administrations expense pay by giving compelling adjusting the hidden resources and the latter is can have positive effect on originators notoriety which in prospects prompts more advance ages capacity which drives the up degree of the appraisals. (Chowdhary, 2011).

However, there is no innate motivation behind why the possibility of components can't have any significant bearing to other social speculations, including those that highlight a social cosmology. Contending from an institutionalist position, Mayntz stresses that once we attempt to comprehend social components, we may find that these small-scale large-scale instruments may not include roused singular conduct to begin with. Institutional and auxiliary segments are conclusive pieces of the miniaturized scale large scale interface: 'If the explanandum is a full scale wonder, or the association between two full scale marvels ... the fundamental intellectual test is in this manner to distinguish the basic and institutional highlights, that sort out ... the activities of various entertainers to deliver their large scale impact' (Mayntz, 2004: 252).

Maybe the clearest asset that is inclined to securitization is transboundary water. Water exchanges and designations as a national security need have just been recognized in different global stream bowls in Southern Africa, for example, the Okavango River bowl (Turton 2003). Not just have various insightful papers been confined around the idea of water securitization, however as of late scholastic projects and water gatherings have been composed around this securitization trendy expression. One model is the Water Security, Risk and Society Conference of 2012 held at Oxford; another is the University of East Anglia Water Security Research Center which tends to water security and related issues. Of late, it appears that as opposed to securitizing the talk around discrete assets, for example, water, nourishment and vitality, scholarly circles have securitized the nexus and the potential negative interchange between these assets. One model is the high profile meeting in Bonn on the Water Energy and Food Security Nexus planned to encourage new cross-sectoral coordinated efforts through such talk (Merdes 2012). 
It is seen that however the auxiliary systems recognized above would not be legitimate without the institutional instruments that set up them as a regular occurrence. Basic institutional estimates that counter dangers may in this manner incorporate the portrayal of military or outside issues authorities in bowl specialists. This is clear in the Nile Basin Initiative, for instance, where the Nile Council of Ministers has been set up as the most elevated dynamic body for the Nile bowl by consolidating clergymen of part nations. A comparative instrument is the inserting of water bargains in higher securityrelated understandings (e.g., harmony settlements), as confirm by the water understandings set inside the Israeli-Jordanian Peace arrangement of 1994 (Israel-Jordan settlement 1994). Another sign of building organizations that legitimize criticalness and security foundation is the rejection of common society and NGO's from administration. The International Boundary and Water Commission (IBWC) is one such model, as this global body accused of giving binational answers for land division and water issues between the USA and Mexico regularly avoids open partners from national fringe and assets issues (Sanchez 1993).

Securitization is a social procedure, more grounded entertainers with more prominent impact have a superior possibility of persuading crowds about the significance and intensity of their securitized issue. Security is in this way an exceedingly organized field where a few on-screen characters are set in better places of intensity (Williams 2003; Buzan et al. 1998), which may additionally sustain the disparities between the individuals who managed to put their issues on the security plan versus the individuals who didn't. At long last, securitization can have negative ramifications since it can prompt the entrance of extra political erosions and contentions into the talk, which in the end will freeze it altogether (Balzacq 2005: 171). This would then be able to prompt less coordinated effort and participation, and eventually to a full stop in the talk of the securitized region (Buzan et al. 1998; Wæver 1995). The water writing, as well, frequently perceives water struggle because of securitization rehearses (Stetter et al. 2011). In fact, given the danger of securitization, researchers taking a shot at nature, for instance, have proposed the elective idea of ecological harmony fabricating, an idea that anxieties participation as opposed to savage choices (Conca and Dabelko 2002). This has been joined by the arrangement of solid instances of the impact of a security system. Along these lines, Dabelko (2009), for instance, portrays how confining environmental change as a factor in the slaughter in Darfur causes push to the foundation the political and financial inspirations for the battlingand accidentally could give the criminal system access Khartoum free.

The supposition that securitization doesn't occur discretionarily (Sjo“"stedt 2010) just as the multiplication of assetbased securitization has brought about some early chips away at the potential factors that energize the utilization of securitization. However, the exploration that uncovered the conditions or factors that support securitization isn't far reaching and frequently appears recounted. Maybe the most obvious variable that may legitimize the utilization of the securitization talk is the event of a disastrous occasion. Emergencies and calamities can speak to edge occasions prompting hierarchical and institutional change where predominant perspectives and acting are dependent upon basic audit and amendment (e.g., Gorg 2003).They may fill in as triggers or impetuses that set up possibly provocative social forms at numerous social levels (Pelling and Dill 2006) including the rejection of common society from arrangement making and the enabling of the military, frequently under the misrepresentation of critical and crisis reactions. In any case, the 2004 Indian Ocean wave additionally represents how debacles legitimize securitization as well as give a "fateful opening" for the other side of securitization- to be specific harmony working in Indonesia (Birkmann et al. 2010).

Wolfe (2000) shows that banks can make an advantage securitization pipeline structure that permits them to improve their arrival on capital methodicallly and more than once. As we clarified, through securitization money related foundations 
can extend their credit arrangement business without expecting to expand their obligation or capital levels. These foundations can enter a procedure of securitization and utilize the money continues to begin new credits so as to rehash the procedure. The new credits will be structured with the expectation of being securitised later on without require extraordinary endeavors as far as examination or elaboration of data. This procedure empowers banks to make numerous credits with a limited quantity of capital utilized. Along these lines, banks efficiently improve their arrival on value.

An extra idea identified with strife and security is power asymmetry, whereby imbalanced force between collaborating gatherings can help in the development of saw dangers (Buzan et al. 1998). This is clear in conversations in regards to future water use and desalination in Israel and Palestine, as switched riparian situating (upstream becomes downstream and the other way around) basically modified each riparian's water power and was suspected as a reason for securitization talk and bombed collaboration (Feitelson 2012).

\section{RESEARCH METHODOLOGY}

For a successful research, defining the objective is very important because it makes clear for the researcher the problem and the ways to find the solutions for it. This project was carried to ascertain the how securitization is Financial Instrument of the New Era. The sample output of a paired samples T test. We compared the mean test scores before (pre-test) and after (post-test) the asset backed security analysis completed a test preparation course. We want to see if our test preparation course improved the performance of Bank. First, we see the descriptive statistics for both variables. This research paper will be analyzing secondary research through research journal, newspaper articles, website, balance sheets, profit and loss accounts etc. This research will be analyzing the data through ratios and descriptive research. This research focuses on studying the research through ratios like the asset turnover ratio, earning per share, debt to equity ratio and the current ratio. We have studied the balance sheet and profit and loss account of ICICI bank and Bank of Rajasthan for the above.

Following are the objective of research: -

- The basic objective to know the future scope or importance \& core functionalities of securitization is Financial Instrument.

- To study performance management in public sector.

- To study the effect of takeover of ICICI bank with bank of Rajasthan on financial instruments.

- To study effect on debt and equity of ICICI bank after takeover.

- $\quad$ After the takeover by ICICI bank its effect on share price in market.

\section{Need \& Significance of the Study}

"Learning and understanding doesn't come except if you yourself experience it ", Really There was part of information accessible on Web to comprehend the Advances elements of any however these were the examinations done by another person and the data were from their own point of view and not what I needed. So to comprehend the Advances capacities in my manner and to find the solution of inquiries that I had in my brain, I did this examination and was extremely fulfilled toward the finish of the task as the entirety of my questions were replied in a methodical way. 


\section{Scope \& Limitations of the Study}

The Scope of this study is very wide and it may take months on months for anybody to study this subject. It was little difficult actually go through each function in much detail and understand. I managed to understand most of the functionalities of securitization are Financial Instrument for future market. This study could be taken forward using the CAPM or the CAMEL model. Since there researcher here wasn't to know the ratio based study application, the study just focuses on the ratios

\section{DATA Analysis Interpretation and Findings}

\section{Hypothesis}

H1 (0): There is no significance difference in financial performance amongst the selected Banks With respect to their pre and post of asset backed securitization Analysis.

$\underline{\mathbf{H}_{\mathbf{1}}(\mathbf{1})}$ : There is a significance difference in financial performance amongst the selected Banks With respect to their pre and post of asset backed securitization Analysis.

$\underline{\mathbf{H}_{2}(\mathbf{0})}$ : There is no significance difference in Earning per Share (EPS) amongst the selected Banks with respect to their pre and post of asset backed securitization Analysis.

H2 (1): There is a significance difference in Earning per Share (EPS) amongst the selected Banks with respect to their pre and post of asset backed securitization Analysis.

\section{Descriptive Table}

\begin{tabular}{|c|c|c|c|c|c|}
\hline & & N & Mean & $\begin{array}{c}\text { Std. } \\
\text { Deviation }\end{array}$ & Std. Error \\
\hline \multirow{2}{*}{$\begin{array}{c}\text { Net_Profit_- } \\
\text { Ratio }\end{array}$} & Pre-asset & 3 & 10.3200 & .54286 & .31342 \\
\cline { 2 - 6 } & Post-asset & 3 & 14.5567 & 2.10165 & 1.21339 \\
\cline { 2 - 6 } & Total & 6 & 12.4383 & 2.69619 & 1.10072 \\
\hline \multirow{3}{*}{ EPS_Ratio } & Pre-asset & 3 & 35.9967 & 2.98791 & 1.72507 \\
\cline { 2 - 6 } & Post-asset & 3 & 45.8400 & 9.99719 & 5.77188 \\
\cline { 2 - 6 } & Total & 6 & 40.9183 & 8.52150 & 3.47889 \\
\hline \multirow{3}{*}{$\begin{array}{c}\text { Debt_Equity } \\
\text { Ratio }\end{array}$} & Pre- asset & 3 & 4.7600 & 4.42539 & 2.55500 \\
\cline { 2 - 6 } & Post- asset & 3 & 4.0800 & .16093 & .09292 \\
\cline { 2 - 6 } & Total & 6 & 4.4200 & 2.82537 & 1.15345 \\
\hline \multirow{2}{*}{$\begin{array}{c}\text { Current_Rat } \\
\text { io }\end{array}$} & Pre- asset & 3 & .5733 & .71591 & .41333 \\
\cline { 2 - 6 } & Post- asset & 3 & .5533 & .67308 & .38860 \\
\cline { 2 - 6 } & Total & 6 & .5633 & .62157 & .25375 \\
\hline
\end{tabular}

\section{Interpretation}

The above table provides us the Statistics regarding MEAN and Std. DEV of the ICICI banks with respect to their pre and post asset backed security analysis. The above analysis shows The Net profit Ratio is deviated 2.69619 from 12.4383 while that of pre-asset ratio is deviated 0.543 from 10.32 and that of post-assets is deviated 2.10 from 14.557, Earning per Share Ratio deviated 8.52150 from 40.9183 while that of pre-asset ratio is deviated 2.98791 from 35.9967 and that of post-assets is deviated 9.99719 from 45.84, Debt/Equity Ratio deviated 2.82537 from 4.4200 while that of pre-asset ratio is deviated 4.42539 from 4.76 which is not much of a deviation and that of post-assets is deviated 0.16093 from 4.080 and Current Ratio is deviated by.62157 from.5633 while that of pre-asset ratio is deviated 0.71591 from 0.5733 and that of post-assets is 
deviated 0.62157 from 0.5633 .

\section{ANOVA Analysis}

The following ANOVA table gives us an insight regarding the existence of significant differences of banks financial performance in India with respect to their pre and post asset backed security analysis. We have taken $95 \%$ level of significance to analyse the data.

\begin{tabular}{|c|c|c|c|c|c|c|}
\hline \multicolumn{7}{|c|}{ ANOVA } \\
\hline & & Sum of Squares & Df & Mean Square & $\mathbf{F}$ & Sig. \\
\hline \multirow{3}{*}{$\begin{array}{l}\text { Net_Profit_Rat } \\
\text { io }\end{array}$} & Between Groups & 26.924 & 1 & 26.924 & 11.429 & .028 \\
\hline & Within Groups & 9.423 & 4 & 2.356 & & \\
\hline & Total & 36.347 & 5 & & & \\
\hline \multirow{3}{*}{ EPS_Ratio } & Between Groups & 145.337 & 1 & 145.337 & 2.670 & .178 \\
\hline & Within Groups & 217.743 & 4 & 54.436 & & \\
\hline & Total & 363.080 & 5 & & & \\
\hline \multirow{3}{*}{$\begin{array}{l}\text { Debt_Equity_R } \\
\text { atio }\end{array}$} & Between Groups & .694 & 1 & .694 & .071 & .803 \\
\hline & Within Groups & 39.220 & 4 & 9.805 & & \\
\hline & Total & 39.914 & 5 & & & \\
\hline \multirow{3}{*}{ Current_Ratio } & Between Groups & .001 & 1 & .001 & .001 & .974 \\
\hline & Within Groups & 1.931 & 4 & .483 & & \\
\hline & Total & 1.932 & 5 & & & \\
\hline
\end{tabular}

\section{Interpretation}

The above analysis shows that there is a significance difference in Earning Per Share Ratio with respect to their pre and post merger analysis which is Earning per Share Ratio deviated 8.52150 from 40.9183 while that of pre-asset ratio is deviated 2.98791 from 35.9967 and that of post-assets is deviated 9.99719 from 45.84, so we accepts the $\underline{\mathbf{H 2}(\mathbf{0})}$ and rejects the $\mathbf{H 2}$ (1). Where as in case of Debt/Equity Ratio and current we reject $\underline{H_{1}(\mathbf{1})}$ and accept $\underline{\mathbf{H}_{\mathbf{0}}(\mathbf{0})}$ with respect to their pre and post merger data analysis at $95 \%$ level of significance. For the Net profit Ratio we accept the alternate hypothesis i.e. $\underline{\mathbf{H}_{\mathbf{1}}(\mathbf{1})}$ and reject $\underline{\mathbf{H}_{0}(\mathbf{0})}$

\section{Paired Samples Statistics}

\begin{tabular}{|l|c|c|c|c|c|}
\hline \multicolumn{2}{|c|}{} & Mean & N & Std. Deviation & $\begin{array}{c}\text { Std. Error } \\
\text { Mean }\end{array}$ \\
\hline Pair 1 & BA_2 & 12.6425 & 4 & 18.46426 & 9.23213 \\
\hline & AA_2 & 16.6225 & 4 & 20.10013 & 10.05007 \\
\hline Pair 2 & BA_3 & 12.3200 & 4 & 14.70034 & 7.35017 \\
\hline & AA_1 & 13.0925 & 4 & 16.15453 & 8.07726 \\
\hline Pair 3 & BA_3 & 12.3200 & 4 & 14.70034 & 7.35017 \\
\hline \multicolumn{7}{|l}{} & AA_3 & 19.0575 & 4 & 25.57052 & 12.78526 \\
\hline
\end{tabular}

\section{Interpretation}

In the above table show that the analysis in paired Sample Statistics Box, the mean for the Pair 1 before asset backed security analysis _2 is 12.6425 where for after asset backed security analysis _2 the mean is 16.6225 .

The Standard Deviation for the before asset backed security analysis _2 is 18.46426 and after asset backed security 
analysis _2 is 20.10013. In Pair 2 before asset backed security analysis _3 is 12.3200 where for after asset backed security analysis _1 the mean is 13.0925 . The Standard Deviation for the before asset backed security analysis_3 is 14.70034 and after asset backed security analysis__ 1 is 16.15453 .

Where in Pair 3 before asset backed security analysis _3 is 12.3200 where for after asset backed security analysis _3 the mean is 19.0575 . The Standard Deviation for the before asset backed security analysis _ 3 is 14.70034 and after asset backed security analysis _3 is 25.57052 . The number of participants in each condition $(\mathrm{N})$ is 4.

Next, we see the correlation between the two variables.

\section{Paired Samples Correlations}

\begin{tabular}{|l|c|c|c|c|}
\hline \multicolumn{2}{|c|}{} & N & Correlation & Sig. \\
\hline Pair 1 & $\begin{array}{c}\text { BA_2 \& } \\
\text { AA_2 }\end{array}$ & 4 & .998 & .002 \\
\hline Pair 2 & $\begin{array}{c}\text { BA_3 \& } \\
\text { AA_1 }\end{array}$ & 4 & .997 & .003 \\
\hline Pair 3 & $\begin{array}{c}\text { BA_3 \& } \\
\text { AA_3 }\end{array}$ & 4 & .999 & .001 \\
\hline
\end{tabular}

In the above table correlation for Pair 1 is 0.998 while the significance is 0.002 and that of pair 2 correlation is 0.997 while the significance is 0.003 . In Pair 3 correlation is 0.999 and the significance is 0.001 . There is a strong positive correlation shows that the Bank performs best not only before asset backed security analysis but also after asset backed security analysis. Finally, we are comparing the results of the Paired Samples T Test. This test is based on the difference between the two variables. Under "Paired Differences" we see the descriptive statistics for the difference between the two variables.

\section{Paired Samples Test}

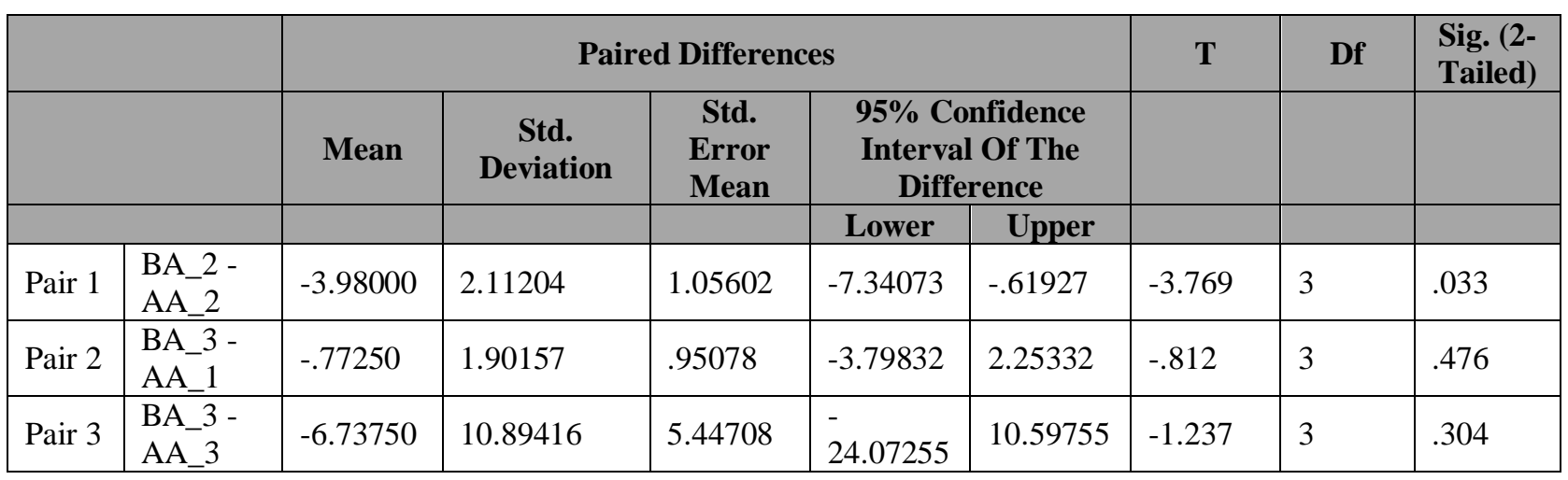

Pair 1

The $T$ value $=\mathbf{- 3 . 7 6 9}$

We have 3 degrees of freedom

Our significance is.033 
Pair 2

The $\mathrm{T}$ value $=-.812$

We have 3 degrees of freedom

Our significance is.476

Pair 3

The $\mathbf{T}$ value $=\mathbf{- 1 . 2 3 7}$

We have 3 degrees of freedom

Our significance is.304

\section{Interpretation}

The above table shows that in Pair 1 we have T-Value is-3.769,Degree of freedom is 3 and Our significance is.033.In Pair 2 we have T-Value is.-812,Degree of freedom is 3 and Our significance is.476. Where is Pair 3 we have T-Value is -1.237 , Degree of freedom is 3 and our significance is.304.

As per the above analysis we can say that according to the standard all the significance value is less than.05 at 95 $\%$ level of significance which shows that there is a significance difference in financial performance amongst the selected Banks with respect to their pre and post asset back security analysis therefore we accept the null hypothesis $\mathbf{H}_{\mathbf{0}}(\mathbf{1})$ and reject the $\mathbf{H}_{\mathbf{1}}$ (1).

\section{CONCLUSIONS}

The investigation of Securitization is of importance in light of the open doors it offers as a wellspring of financing to a creating nation like India. It is especially valuable for Banks and in the financing of reserve starved framework ventures. Presently out of nowhere driving bank are offloading credits worth a large number of crores in the optional market through the securitization course. The customary drivers of securitization have seen the longing of the guarantor to get minimal effort assets, through new sources, in a cockeyed sheet way. This has roused different establishments to go in for securitization. Capital Markets affirm the pattern expressing that volumes of securitized issues orchestrated by them this year have been practically twofold that last year. Another pioneer in securitization, Citibank, has finished up a few arrangements, which incorporates a securitization of the bank's very own credit portfolio. In addition, lodging account major HDFC which securitized a pool of around Rs 356 crore advance resources in the primary quarter of '07-08, CANFIN Homes, the lodging fund arm of Canara Bank, has securitized one more pool of lodging credits receivables and has just raised Rs 156 crore. Kotak Mahindra Fund has securitized business vehicle advances worth Rs 76 crore. Speculator intrigue also is vastly improved. While attempting to sell the NHB's sold sponsored protections issue, it took three weeks to persuade the financial specialists. Be that as it may, this time around, the issue was sold in three days. What's more, passing by the appraisal's patterns of securitized paper by the four rating offices in the nation could well be a marker of state of things to come in the market. A major lift for securitization has been the presentation of the Securitization and Remaking of Money related Resources and Implementation of Security Interest. Since the late eighties, when securitization made its start in India, the number just as the size of exchanges has become throughout the years. This pattern is probably going to proceed and the market would observer impressive development in the coming years. The principle rousing element in securitization 
exchanges in the past has been the administration of capital ampleness. While this would keep on being the interest driver, securitization is probably going to be progressively utilized for better resource obligation the board, presentation the board, forthright benefit booking, and so on.

\section{REFERENCES}

1. Balzacq, T. (2005). The three faces of securitization: Political agency, audience and context. European Journal of International Relations, 11(2), 171-201.

2. Birkmann, P. B., Jaeger, J., Pelling, M., Setiadi, N., Garschagen, M., Fernando, N., \& Kropp, J. (2010). Extreme events and disasters: A window of opportunity for change? Analysis of organizational, institutional and political changes, formal and informal responses after mega-disasters. Natural Hazards, 55(3), 637-655

3. Buzan, B., Waver, O., \& de Wilde, J. (1998). Security: A new framework for analysis. Boulder, CO: Lynne Rienner Publications

4. Conca, K., \& Dabelko, G. D. (2002). Environmental peacemaking. Washington: Johns Hopkins University Press.

5. Chowdhury, A. (2011). Securitisation, a Primer. Tata McGraw-Hill Education.

6. Dabelko, G. (2009). Avoid hyperbole, oversimplification when climate and security meet. Bulletin of the Atomic Scientists, August, 24. http://thebulletin.org/avoid-hyperbole-oversimplification-when-climateand-security-meet

7. Davidson, A., Sanders, A., Wolff, L. L., \& Ching, A. (2004). Securitization: structuring and investment analysis (Vol. 285). John Wiley \& Sons.

8. Feitelson, E. (2012). The Water Security Implications of Water Securitization presented at the Water Security, Risk and Society Conference, Oxford. 15-17 April, 2012.

9. Gorg, C. (2003). Regulation der Naturverhallnisse. Zu einer kritischen Regulation der o*kologischen Krise.Westfa"lisches Dampfboot, Münster

10. Israel- Jordan Treaty. 1994. Treaty of Peace Between the State of Israel and the Hashemite Kingdom of Jordan. October 26, 1994. https://www.knesset.gov.il/process/docs/peace-jordan_eng.htm

11. Kothari, V. (2006). Securitization: The Financial Instrument of the Future. Wiley Finance, John Wiley and Sons, Singapore.

12. Pelling, M. \& Dill, K. (2006). Natural disasters as catalysts of political action. Chatham house. ISP/NSC Briefing Paper 06/01, pp. 4-6.

13. Pennacchi, George G. (1988). "Loan sale and the Cost of Banking Capital" Journal of Finance, 43, 375-96.

14. Sanchez, R. (1993). Public participation and the IBWC: Challenges and options. Natural Resources Journal, 33, 283

15. Stetter, S., Herschinger, E., Teichler, T., \& Albert, M. (2011). Conflicts about water: Securitizations in a global context. Cooperation and Conflict, 46, 441

16. Sjo"stedt, R. (2008). Exploring the construction of threats: The securitization of HIV/AIDS in Russia. Security 
Dialogue, 39(1), 7-29

17. Vinod Kothari (1999) The Financial Instrument of the New Millennium : Comprehensive Treatise on the Most Important Financial Instrument of Our Time; Academy of Financial Services, 1999

18. Waver, O. (1995). Securitization and desecuritization. In R. Lipschutz (Ed.), On security (pp. 46-86). New York: Columbia University Press

19. Williams, M. C. (2003). Words, images, enemies: Securitization and international politics. International Studies Quarterly, 47(4), 511-531.

20. Wolfe, S., 2000, Structural effects of asset backed securization, European Journal of Finance 6, 353-369.

\section{Articles in}

- The Economic Times

- The Financial Express

- The Business Standard

- Crisil Report on Securitization

\section{Structured Obligation}

- Indian MBS Market: On a growth trajectory

- The Indian Auto Loan Securitization Market: - Geared for Growth

\section{WEBLIOGRAPHY}

- www.vinodkothari.com

- $\quad$ www.crisil.com

- www.globalsecuritisation.com

- $\quad$ www.asset-backed.com 

